\section{Managing Conception and Pregnancy for HIV Serodiscordant Couple: A Case Report}

\author{
SAPIEE $\mathbf{S}^{1}$, LEELAVATHI $\mathbf{M}^{2}$ \\ ${ }^{1}$ KLINIK KESIHATAN KAJANG, JALAN SEMENYIH, 43000 KAJANG, SELANGOR \\ ${ }^{2}$ Department of Family Medicine, Faculty of Medicine, Universiti Kebangsaan Malaysia \\ Medical Centre, Jalan Yaacob Latif, Bandar Tun Razak, 56000 Cheras, Kuala Lumpur, \\ Malaysia.
}

\begin{abstract}
ABSTRAK
Terdapat peningkatan bilangan orang yang hidup dengan HIV dan AIDS terutama dalam kumpulan usia muda. Ini akan memberi impak besar apabila mereka inginkan cahaya mata. Perancangan proses mengandung di kalangan pasangan yang berlainan status HIV (serodiscordant) adalah rumit terutama dalam isu mengurangkan risiko penularan penyakit. Kami melaporkan kes seorang lelaki HIV positif dan isteri beliau (HIV negatif) yang berjaya mengadung dan melahirkan anak yang sihat tanpa penyebaran penyakit HIV kepada ibu atau anak. Pasangan ini telah diuruskan dengan rawatan di mana pasangan lelaki HIV positif dirawat dengan HAART manakala pasangan wanita yang HIV negatif menerima rawatan dengan PrEP. Konsepsi berjaya dicapai melalui teknik IUI. Perancang untuk konsepsi, rawatan dengan ubatan dan pilihan cara konsepi adalah antara isu penting yang akan dibincangkan secara terperinci.
\end{abstract}

Kata kunci: jangkitan HIV, pasangan serodiscordant, terapi antiretroviral

\section{ABSTRACT}

Worldwide, there is an increasing number of people living with HIV and AIDS especially in the reproductive age group. This has a huge impact when they wish to start a family. Managing reproductive issues among serodiscordant HIV couples is complex and often presents as a challenge especially in minimizing the risk of transmission. We report a case of a HIV positive man and his seronegative wife who successfully achieve conception and deliver a healthy baby without disease transmission of HIV to mother or child. Both partners were managed with treatment where the HIV positive male partner was treated with HAART while

Address for correspondence and reprint requests: Assoc. Prof. Dr. Leelavathi Muthupalaniappen. Department of Family Medicine, Faculty of Medicine, Universiti Kebangsaan Malaysia Medical Centre, Jalan Yaacob Latif, Bandar Tun Razak, 56000 Cheras, Kuala Lumpur, Malaysia. Tel: +603-91459475 Email: drleelaraj@gmail.com 
the unaffected female partner was on PrEP and conception was achieved through intrauterine insemination (IUI). Planning of conception, the use of medications and options for conception methods will be discussed in detail.

Keywords: antiretroviral therapy, HIV infection, serodiscordant couples

\section{INTRODUCTION}

With invent of Highly Active Antiretroviral Therapy (HAART), People Living with HIV and AIDS around the world are able to live longer and a more fulfilled life. A new challenge awaits them when they plan to start a family. Preparing a serodiscordant couple for pregnancy requires proper planning. Education regarding risk of HIV transmission to the uninfected partner and the newborn is an important aspect (Mason et al. 2017).

Insemination of HIV negative women with semen from a HIV positive man is prohibited to minimize sexual transmission of the disease. Adoption or inseminations with HIV negative donor sperm are other options to reduce risk of disease transmission to achieve zero HIV infection among newborns (Strategies for Preventing HIV Infection 2017). Recently, Centers for Disease Control and Prevention (CDC) has suggested strategies to reduce transmission which requires both partners to be on treatment. The strategy includes viral suppression with HAART for the affected male partner while the unaffected female partner takes daily oral antiretroviral pre-exposure prophylaxis (PrEP) during pre-conception period. Conception is then planned either through natural unprotected intercourse limited during ovulation period or through assisted reproductive techniques (ART) (Strategies for Preventing HIV Infection 2017). The risk of transmission, efficacy of treatment and the cost are factors affecting the decision on the method of conception.

We report the case of a HIV positive male and his HIV negative female partner who successfully conceive and deliver a healthy baby without disease transmission to mother or child through successful preconception management and assisted conception.

\section{CASE REPORT}

A 35-year-old man HIV positive man and his HIV negative wife have been married for 4 months. They had been practicing barrier method of contraception since marriage to prevent pregnancy and transmission of HIV. The couple sought consultation at the primary care clinic as they were keen for conception. The HIV positive male partner had been on HAART since diagnosis. After 5 months of treatment, his HIV RNA viral load was successfully suppressed to undetectable level. The patient and his wife were screened and found to be free of any infertility issues, medical 
or sexually transmitted diseases. They were counseled together regarding medication, appropriate timing for conception, the risk of disease transmission to mother, child and safe conception options.

After discussion with a multidisciplinary team consisting of primary care physician, obstetrician and the infectious disease physician on options for conception method, the cost and the risk involved, the couple opted for the ART method of conception using IUI. The couple was managed with HAART for the affected male partner and daily preexposure prophylaxis (PrEP) with Truvada (combination of tenofovir and emtricitabine) for his wife. Truvada was started one month before the planned conception. Conception was achieved at the $2^{\text {nd }}$ IUI session using sperm washing technique. She was then monitered with regular antenatal follow up and three monthly HIV screening throughout the pregnancy. Her pregnancy was uneventful and the couple delivered a full term healthy baby boy through spontaneous vaginal delivery without disease transmission to mother or baby.

\section{DISCUSSION}

Safe conception among serodiscordant couples can be achieved if appropriate risk-reduction strategies are applied. Preparation for pregnancy for this couple started well before pregnancy. Fertility assessment for the couple was made to minimize exposure of the uninfected partner during trial of conception as HIV itself can affect fertility (Strategies for Preventing HIV Infection 2017). Trial of natural method of conception may not be worthwhile if the positive male partner has infertility issues such as oligospermia or azoospermia. In such cases ART would be more suitable.

Treatment of the HIV positive male partner with HAART suppresses HIV RNA plasma viral level. Risk of disease transmission is lower when the viral load level is undetectable (Matthews et al. 2012). However this does not confer complete protection to the unaffected female partner as viral levels in the plasma and seminal fluid may or not be parallel suggesting a potential risk for transmission, albeit low. The risk of transmission can be further reduced if HAART for the HIV positive male partner is combined with PrEP for the HIV negative female partner (Lasry et al. 2014; Strategies for Preventing HIV Infection 2017). PrEP reduces HIV transmission and is indicated for the uninfected female partner planning to conceive. Truvada, which is a combination of tenofovir and emtricitabine is the drug of choice PrEP approved by U.S. FDA (Bazzi et al. 2017) uninfected female Tenofovir and emtricitabine are also considered safe as both these drugs did not show any teratogenic effects in animal models.

When the positive male partner has undetectable HIV RNA plasma viral load level with treatment, conception may be achieved either by natural method or by using ART. This couple opted for ART using IUI method of conception after being explained that the risks of infection is lower with this technique when combined with 
sperm washing. "Sperm washing" technique involves centrifuging the seminal fluid to separate the sperm from the semen and the lymphocytes where the virus resides thus rendering 92 to $99 \%$ of the specimens to be free of the virus. This washed sperm is then used for insemination either by Intrauterine Insemination (IUI), In-vitro fertilization (IVF) or Intracytoplasmic Sperm Injection (ICSI) (Strategies for Preventing HIV Infection 2017). The sperm washing method has been shown to significantly reduce HIV infection in the serodiscordant partner and the offspring (Matthews et al. 2012). However ARTs are expensive runs the risk of failed procedure. This procedure may not be widely available as it requires good laboratory facilities and trained medical staff.

Another option for method of conception while the affected male partner is HAART and the unaffected female partner is on PrEP is through unprotected sexual intercourse (without male condom) limited to 3 days during the ovulation window (2 days before ovulation and on the ovulation day) during one menstrual cycle (Hoffman et al. 2015; Strategies for Preventing HIV Infection 2017). PreP must be started 20 days before vaginal intercourse. It provides more than $90 \%$ protection against disease transmission of HIV from sexual contact provided there is good adherence to treatment (Bazzi et al. 2017; Strategies for Preventing HIV Infection 2017). During this trial of conception period, the HIV negative female partner must be screened for HIV every three-monthly. After the trial of conception period, the HIV positive male partner must revert to condom use to prevent HIV transmission.

Upon conception though either one method, the uninfected female partner must be continuously monitored for seroconversion at every trimester although the risk is low. If she does not acquire HIV during the pregnancy, she would require regular scheduled antenatal care and may be allowed for spontaneous vaginal delivery if there are no other contraindications. Should she become HIV positive at any point of pregnancy, antiretroviral therapy should be started to minimize perinatal infection to the fetus regardless of viral load and CD4 count aiming to keep the viral load at an undetectable level. If she acquires HIV with a viral load at the time of delivery of more than 1000 , then the recommended mode of delivery is via elective cesarean section with intrapartum IV Zidovudine to minimize perinatal transmission of HIV. The newborn will also require antiretroviral treatment upon delivery. In event mother is infected, HAART must be continued for life and breastfeeding is contraindicated to minimize HIV transmission (Aids info Recommendations 2018)

\section{CONCLUSION}

Managing HIV serodiscordant couples who desire children is very challenging. This issue needs to be addressed without any discrimination using the latest available management and risk-reduction strategies The main aim is to reduce the risk of HIV transmission to the uninfected partner and to achieve zero infection 
to the newborn. For this to happen, a dedicated multidisciplinary team need to work together to ensure a safe outcome for mother and child. Good rapport, shared care decision making and understanding between doctor, patient and his partner are important factors which will ensure a safe and successful journey to parenthood.

\section{REFERENCES}

Aids info Recommendations for Use of Antiretroviral Drugs in Pregnant HIV-1-Infected Women for Maternal Health and Interventions to Reduce Perinatal HIV Transmission in the United States $2018 . \quad$ https://aidsinfo.nih.gov/contentfiles/ Ivguidelines/PerinatalGL.pdf [27 $7^{\text {th }}$ June 2018

Bazzi, A.R., Leech, A.A., Biancarelli, D.L., Sullivan, M., Drainoni, M.L. 2017. Experiences using pre-exposure prophylaxis for safer conception among hiv serodiscordant heterosexual couples in the United States. AIDS Patient Care and STDS 31(8): 348-55.

Hoffman, R.M., Jaycocks, A., Vardavas, R., Wagner G,. Lake, J.E., Mindry, D., Currier, J.S., Landovitz, R.J. 2015. Benefits of PrEP as an adjunctive method of HIV prevention during attempted conception between HIV-uninfected women and hivinfected male partners. J Infect Dis 212(10): 1534-43.
Lasry, A., Sansom, S.L., Wolitski, R.J., Green, T.A., Borkowf, C.B., Patel, P., Mermin, J. 2014. HIV sexual transmission risk among serodiscordant couples: Assessing the effects of combining prevention strategies. Aids 28(10): 1521-9.

Mason, J., Medley, A., Yeiser, S., Nightingale, V.R., Mani, N., Sripipatana, T., Abutu, A., Johnston, B., Watts, D.H. 2017. The role of family planning in achieving safe pregnancy for serodiscordant couples: Commentary from the United States government's interagency task force on family planning and HIV service integration. J Int AIDS Soc 20(Suppl 1): 4-11.

Matthews, L.T., Smit, J.A., Cu-Uvin, S., Cohan, D. 2012. Antiretrovirals and safer conception for HIV-serodiscordant couples. Curr Opin HIV AIDS 7(6): 569-78.

Strategies for Preventing HIV Infection Among HIVUninfected Women Attempting Conception with HIV-Infected Men - United States. 2017. 66(21): 554-7. https://www.cdc.gov/mmwr/ volumes/66/wr/mm6621a2.htm [27 ${ }^{\text {th }}$ June 2018$\}$

Received: 23 Jul 2018

Accepted: 28 Nov 2018 